\title{
Musculoskeletal Disorders and Its Related Factors among Workers in Circulator Loom Unit
}

\section{Musculoskeletal Disorders dan Faktor yang Berhubungan pada Pekerja di Unit Circulator Loom}

\author{
Dian Rachmawati, Sho'im Hidayat \\ Department of Occupational Safety and Health, Faculty of Public Health Universitas Airlangga \\ Campus C Mulyorejo, Surabaya, East Java 60115Indonesia
}

\begin{abstract}
Introduction: Musculoskeletal Disorders (MSDs) defined as a disorder of muscles, nerves, and tendons compounded by the unergonomic working posture. Workers in Circulator Loom Unit of PT. Kerta Rajasa Raya are at risk for experiencing MSDs because of their unergonomic works. The purpose of this research was to learn more about MSDs including its related factors in Circulator Loom unit of PT. Kerja Rajasa Raya workers. Methods: This was a descriptive research which conducted using the observational method. The respondents were total population workers of Circulator Loom Unit at PT Kerta Rajasa Raya which is up to 47 workers. This research used MSDs complaint, working postures, and individual factors including age, sex, working period, physical fitness, and body mass index as the variable data. Results: $91.5 \%$ respondents were experiencing MSDs with $53.5 \%$ were in moderate severity level. Using REBA method to calculate the ergonomic risk level, it can be concluded that $23.4 \%$ of respondents have low risk of experiencing MSDs, $68.1 \%$ in medium risk, and $8.5 \%$ of respondents were having high risk of experiencing MSDs. Conclusion: Working posture was the most influential factor causing MSDs with correlation coefficient score 0.629 , in addition, working period, age, sex, Body Mass Index, and physical fitness were existed as supporting factors.
\end{abstract}

Keywords: ergonomic, musculoskeletal disorders, working posture

\begin{abstract}
ABSTRAK
Pendahuluan: Musculoskeletal Disorders (MSDs) merupakan suatu keluhan berupa rasa nyeri yang terjadi pada otot, syaraf, dan tendon yang disebabkan dan diperparah oleh postur kerja yang tidak ergonomis. Pekerja di unit Circulator Loom PT. Kerta Rajasa Raya berisiko untuk mengalami MSDs karena pekerjaannya yang tidak ergonomis. Penelitian ini bertujuan untuk mempelajari MSDs dan faktor yang berhubungan pada pekerja di unit Circulator Loom PT. Kerta Rajasa Raya. Metode: Penelitian ini merupakan penelitian deskriptif dengan metode observasional. Responden dalam penelitian ini menggunakan towtal populasi pekerja di unit Circulator Loom PT. Kerta Rajasa Raya yang berjumlah 47 orang. Variabel yang akan diteliti adalah keluhan MSDs, postur kerja, dan faktor individu meliputi umur, jenis kelamin, masa kerja, kebugaran jasmani, Indeks Massa Tubuh. Hasil: 91,5\% responden mengalami keluhan MSDs dan sebesar 53,5\% mengalamai keparahan sedang. Tingkat risiko ergonomi dihitung menggunakan metode REBA didapatkan sebanyak 23,4\% memiliki risiko rendah, 68,1\% memiliki risiko sedang, dan 8,5\% memiliki risiko tinggi. Simpulan: Postur kerja merupakan faktor yang paling penting dalam terjadinya MSDs dengan nilai correlation coefficient 0,629, selain itu faktor masa kerja umur, jenis kelamin, Indeks Massa Tubuh, dan kebugaran jasmani merupakan faktor lain yang mungkin dapat berperan dalam terjadinya MSDs.
\end{abstract}

Kata kunci: ergonomi, musculoskeletal disorders, postur kerja

Author for Correspondence:

Dian Rachmawati

Email: dianrchmwt@yahoo.com

Telephone: +6281280001516

\section{INTRODUCTION}

Every workplace has its own potential hazard in job activities. The potential hazard is something that might occur during an incident that resulted in losses (International Labour Organization, 2013). Potential hazard in workplaces may cause risks that affect the

C)2019 IJOSH. Open access under CC BY NC-SA license doi: 10.20473/ijosh.v8i3.2019.265-273. Received December 13, 2018, received in revised form January 18, 2019, Accepted November 04, 2019, Published: December 2019 
health of workers. One of the potential hazard in the workplace that raise number of health disorders are ergonomics factors.

The impact of the absence of ergonomic factor in job activity is the occurrence of musculoskeletal disorders (MSDs) complaint. The MSDs complaint is a complaint on the skeletal muscle parts of several injury on joints, ligaments and tendons perceived by someone started from mild to severe complaints. Then, the complaints occur when muscles receive a repeatedly static burden for a long period or time (Tarwaka, 2013). MSDs can be episodic or chronic in duration and also result from injury sustained in a work-related accident (Health and Safety Executive, 2017).

MSDs is known for its high influence on the quality of life, such as loss a working time or absent, adding working restrictions, transferring to other jobs, and disability risks (Khudhir et al., 2017). Based on the Bureau of Labor Statistic (2017) data 2016 , there is $32 \%$ complaints of MSDs in industrial sector that caused the workers having rest at home. It also occur $29.4 \%$ per 10,000 cases of full-time workers.

The MSDs can be caused by two factors that are categorized as internal and external factor. Internal factor is a factor which is based on the individuals, which is not directly related to their job. The individual factors include age, gender, working period, smoking habits, physical fitness and body mass index. On the other side, the external factor is a factor that relates to their work such as unnatural working positions, working shifts, vibrations, pressures, and working climate (Tarwaka, 2013).

The maximum strength of muscles occurs in the age of 20 to 29 , but it would gradually decreased on following the age. Someone whose age is 60 year old has decreased muscles strength up to $20 \%$ of the previous. Thus, the risk of MSDs will increase (Tarwaka, 2013).

Khudhir et al. (2017) showed that the prevalence of MSDs on female nurses is higher than the male nurses. It happens because female's muscle strength is only two-thirds of male's muscle strength. Thus, male's muscle endurance is higher than female (Tarwaka, 2013).

Working period is the length of someone's work which relates to the length of one person's exposure to the risk in the workplace. The longer tenure passed, the more the risk of MSDs exposed. Randang, Kawatu and Sumampouw (2017) proved that there is a relationship between musculoskeletal complaints and the working period of fisherman at Talikuran, Remboken Regency sub-district of Minahasa.

Physical fitness can also affect MSDs due to its related component to health such as cardio respiratory endurance, muscular endurance, muscular strength, body composition, and flexibility (Caspersen, Powell and Christenson, 1985).

Overweight people may decrease their own stability of posture and potentially add negative effects on controlling the upper extremities' movement. Moreover, weight can be a factor that contributes to the increasing mass on physiology and mechanics on tissues (Sethi, Sandhu and Imbanathan, 2011).

The MSDs complaint is generally experienced by workers who have to deal with heavy physical works, working postures, static postures, unnatural posture like frequent bending and twisting muscles of the back, lifting, pushing and pulling the back, doing the same in repetitive motion, vibration, psychological and psychosocial stress (Ghosh, 2015). Ghosh (2015) study on goldsmith in India shows that the occurrence of MSDs due to the unnatural posture with bending forward motion may create pain on the lower back and neck area.

PT. Kerta Rajasa Raya is a company that produces plastic sacks. In the Circulator Loom Unit, there is knitting process that requires 166 machines which are operated by operators. They work in standing position and perform repetitive motion. The operators replaced the skein of yarn with nonergonomic posture such as twisting muscles and bending the back, while their hands position is higher than shoulder. That condition influences the occurrence of MSDs. Based on the interview with one of the operators, they stated they have pain on their legs, back, and hands. However, based on an interview with the representatives of PT Kerta Rajasa Raya, they haven't received any records of the workers' complaint on MSDs problem.

The purpose of this research is to study about MSDs and its related factors among workers in the Circulator Loom Unit of PT. Kerta Rajasa Raya.

\section{METHODS}

This research used a descriptive research which conducted using the observational method. The respondents of this research used total population 
workers of Circulator Loom Unit at PT Kerta Rajasa Raya which is up to 47 workers. The research was held in April to November 2018.

This research used MSDs complaint, working postures, and individual factors including age, sex, working period, physical fitness, and body mass index as the variable data. The data was obtained through interviewing the workers by using questionnaires, measurement of body mass index, physical fitness measurement by Harvard step up tests method, and observing the working postures. The measurement of working postures used REBA method. The result of the assessment of risk levels showed REBA ergonomics which was categorized into 5 levels from the lowest to the highest. The Measurement of MSDs used Nordic Body Map (NBM) method by interviewing the workers about which body parts had the musculoskeletal disorders. Then, the level of complaint was categorized into 4 levels (lowest to the highest).

Data obtained will be processed and analyzed descriptively and then showed by a form of frequency table and cross tabulation. Meanwhile, to discover the correlation among variables and MSDs, this research undertake correlation test to reveal correlation coefficient and chi test is undertaken as well to obtain contingency coefficient value.

\section{RESULT}

\section{An Overview of the Work in the Circulator Loom Unit of PT. Kerta Rajasa Raya}

In the Circulator Loom Unit, the yarn-shaped spindles plastic from Extruder Unit is processed. These yarns are woven and knitted to become fabric or sheet of sack. The production process used 166 machines which were operated by the operators. The task of the operators is to enter new spindles of yarn immediately into the machine when the spindles of yarn are running out. The operators worked with

Table 1. Distribution of Respondents by MSDs Complaint in Circulator Loom Unit of PT. Kerta Rajasa Raya in 2018

\begin{tabular}{ccc}
\hline MSDs Complaint & Frequency (n) & Percentage (\%) \\
\hline Yes & 43 & 91.5 \\
No & 4 & 8.5 \\
\hline Total & 47 & 100 \\
\hline
\end{tabular}

standing position and occasionally worked in nonergonomic posture such as twisting muscle of the back, bending the back, and hand positioned above the shoulder for quite a long time. This condition occurs in all day and it becomes the operators' routine, thus they have MSDs risk. Below is the picture of the the operators' work at the Circulator Loom Unit.

Besides the operators, the work in the Circulator Loom Unit was the courier who is in charge in funneling the spindles of yarn from the Extruder Unit to the Circulator Loom Unit. The work was carried out using the trolley aids. However, the transported logs consists of several baskets with a very heavy loads. The work was carried out every day so that the employees.

\section{MSDs Complaints}

The data on MSDs complaints experienced by the workers in Circulator Loom Unit of PT. Kerta Rajasa Raya were divided into two categories namely Yes and No. The result of data collection were shown in Table 1. As Table 1 shows, as many as 43 workers $(91.5 \%)$ had MSDs complaint and 4 other $(8.5 \%)$ did not suffer MSDs complaint.

\section{MSDs Severity Level}

Data of severity level experienced by the workers in Circulator Loom Unit of PT. Kerta Rajasa Raya that was obtained from the Nordic Body Map questionnaire can be seen in Table 2 . Based on the MSDs severity level distribution on workers in Circulator Loom Unit of PT. Kerta Rajasa Raya in Table 2, the moderate severity level was experienced the most by the workers with 23 respondents $(53.5 \%)$.

\section{Risk of MSDs Occurrence Based on Working Posture}

Employees working posture risk in Circulator Loom Unit of PT. Kerta Rajasa Raya was measured using REBA method. The results of measurement will show the risk level caused by the working posture. Based on the research, the score's result was obtained through the REBA method as in Table 3 . Largely, the workers working posture risk in the Circulator Loom Unit PT Kerta Rajasa Raya included to the medium risk category with 32 respondents $(68.1 \%)$. 


\section{Individual Factor}

Age

Workers age distribution in Circulator Loom Unit of PT. Kerta Rajasa Raya used the median as a cut off, presented in Table 4. As presented in the Table 4, most of the workers age in Circulator Loom Unit of PT. Kerta Rajasa Raya was $<44$ Years Old $(51.1 \%)$.

Sex

The result showed that mostly, workers in Circulator Loom Unit of PT. Kerta Rajasa Raya were female with total 39 respondents (83\%). Distribution of Respondents by sex can be seen in Table 5 .

\section{Working Period}

Working period distribution of workers in Circulator Loom Unit of PT. Kerta Rajasa Raya used the median as a cut off, can be seen in Table

Table 2. Distribution of Respondents by the MSDs Severity Level in Circulator Loom Unit of PT. Kerta Rajasa Raya in 2018

\begin{tabular}{ccc}
\hline $\begin{array}{c}\text { MSDs Severity } \\
\text { Level }\end{array}$ & Frequency (n) & Percentage (\%) \\
\hline Mild & 12 & 27.9 \\
Moderate & 23 & 53.5 \\
Severe & 8 & 18.6 \\
\hline Total & 43 & 100 \\
\hline
\end{tabular}

Table 3. Distribution of Respondents by Workers Working Posture Risk in Circulator Loom Unit of PT. Kerta Rajasa Raya in 2018

\begin{tabular}{ccc}
\hline Risk Level & Frequency (n) & Percentage (\%) \\
\hline Low & 11 & 23.4 \\
Medium & 32 & 68.1 \\
High & 4 & 8.5 \\
\hline Total & 47 & 100 \\
\hline
\end{tabular}

Table 4. Distribution of Respondents by Age in Circulator Loom Unit of PT. Kerta Rajasa Raya in 2018

\begin{tabular}{ccc}
\hline Age (Years) & Frequency (n) & Percentage (\%) \\
\hline$<44$ & 24 & 51.1 \\
$\geq 44$ & 23 & 48.9 \\
\hline Total & 47 & 100 \\
\hline
\end{tabular}

6. As presented in the Table 6, most of the workers working period in Circulator Loom Unit of PT. Kerta Rajasa Raya was $<20$ Years Old (51.1\%).

\section{Physical Fitness}

Workers physical fitness distribution in Circulator Loom Unit of PT. Kerta Rajasa Raya can be seen in Table 7. As the Table 7 depicts, most of the respondents had less physical fitness as many as 43 respondents $(91.5 \%)$ and the rest had moderate physical fitness as many as 4 respondents $(8.5 \%)$.

Table 5. Distribution of Respondents by Sex in Circulator Loom Unit of PT. Kerta Rajasa Raya in 2018

\begin{tabular}{ccc}
\hline Sex & Frequency $(\mathbf{n})$ & Percentage $\mathbf{( \% )}$ \\
\hline Male & 8 & 17 \\
Female & 39 & 83 \\
\hline Total & 47 & 100 \\
\hline
\end{tabular}

Table 6. Distribution of Respondents by Working Period in The Circulator Loom Unit PT. Kerta Rajasa in 2018

\begin{tabular}{ccc}
\hline Working Period & Frequency (n) & Percentage (\%) \\
\hline$<20$ Years Old & 24 & 51.1 \\
$\geq 20$ Years Old & 23 & 48.9 \\
\hline Total & 47 & 100 \\
\hline
\end{tabular}

Table 7. Distribution of Respondents by Physical Fitness in Circulator Loom Unit of PT. Kerta Rajasa Raya in 2018

\begin{tabular}{ccc}
\hline Physical Fitness & Frequency (n) & Percentage (\%) \\
\hline Less & 43 & 91.5 \\
Moderate & 4 & 8.5 \\
\hline Total & 47 & 100 \\
\hline
\end{tabular}

Table 8. Distribution of Respondents by BodyMass-Index in Circulator Loom Unit of PT. Kerta Rajasa Raya in 2018

\begin{tabular}{ccc}
\hline Body Mass Index & Frequency (n) & Percentage (\%) \\
\hline Underweight & 1 & 2.1 \\
Normal & 19 & 40.4 \\
Overweight & 27 & 57.5 \\
\hline Total & 47 & 100 \\
\hline
\end{tabular}




\section{Body-Mass-Index}

Body-Mass-Index data was gained through a measurement of body weight divided body height square in meter. Based on the data from the questionnaire, body mass index was categorized into three namely underweight, normal weight, overweight that is presented in Table 8 . Table 8 shows that most of the respondents belonged to Overweight category with 27 respondents (59.5\%).

The Working-Posture Based Cross Tabulation of Workers with MSDs in Circulator Loom Unit of PT. Kerta Rajasa Raya

Table 9 showed that from 11 respondents in low risk working posture group, 4 respondents $(36.4 \%)$ did not suffer from MSDs and the other
7 respondents $(63.6 \%)$ suffered from mild severity MSDs. Meanwhile, respondents in the medium risk group were mostly suffered from moderate severity MSDs with 21 respondents (65.6\%). Likewise for respondents in high risk group: most of them $(50 \%)$ suffered from MSDs with moderate severity level Based on the correlation test result, the correlation coefficient score was 0.629 . It showed a strong correlation between working posture and MSDs.

The Age Based Cross Tabulation with MSDs on Workers in Circulator Loom Unit of PT. Kerta Rajasa Raya

Table 9 showed that in the $<44$ years old group respondents, 4 respondents $(16.6 \%)$ did not suffer from MSDs, 7 respondents $(41.7 \%)$ suffered from MSDs with moderate severity level, 10 respondents

Table 9. The Working Posture and Individual Factors Based Cross Tabulation of Workers with MSDs in Circulator Loom Unit of PT. Kerta Rajasa Raya in 2018

\begin{tabular}{|c|c|c|c|c|c|c|c|c|c|c|}
\hline \multirow{3}{*}{ Factors } & \multicolumn{8}{|c|}{ MSDs } & \multirow{2}{*}{\multicolumn{2}{|c|}{ Total }} \\
\hline & \multicolumn{2}{|c|}{ No MSDs } & \multicolumn{2}{|c|}{ Mild } & \multicolumn{2}{|c|}{ Moderate } & \multicolumn{2}{|c|}{ Severe } & & \\
\hline & $\mathbf{n}$ & $\%$ & $\mathbf{n}$ & $\%$ & $\mathbf{n}$ & $\%$ & n & $\%$ & $\mathbf{N}$ & $\%$ \\
\hline \multicolumn{11}{|c|}{ Working Posture } \\
\hline Low Risk & 4 & 36.4 & 7 & 63.6 & 0 & 0 & 0 & 0 & 11 & 100 \\
\hline Medium Risk & 0 & 0 & 4 & 12.5 & 21 & 65.6 & 7 & 21.9 & 32 & 100 \\
\hline High Risk & 0 & 0 & 1 & 25 & 2 & 50 & 1 & 25 & 4 & 100 \\
\hline Total & 4 & 8.5 & 12 & 25.5 & 23 & 48.9 & 8 & 17.1 & 47 & 100 \\
\hline \multicolumn{11}{|l|}{ Age (Years) } \\
\hline$<44$ & 4 & 16.6 & 7 & 29.2 & 10 & 41.7 & 3 & 12.5 & 24 & 100 \\
\hline$\geq 44$ & 0 & 0 & 5 & 21.7 & 13 & 56.5 & 5 & 21.7 & 23 & 100 \\
\hline Total & 4 & 8.5 & 12 & 25.5 & 23 & 48.9 & 8 & 17.1 & 47 & 100 \\
\hline \multicolumn{11}{|l|}{ Sex } \\
\hline Male & 0 & 0 & 5 & 62.5 & 2 & 25 & 1 & 12.5 & 8 & 100 \\
\hline Female & 4 & 10.25 & 7 & 17.95 & 21 & 53.85 & 7 & 17.95 & 39 & 100 \\
\hline Total & 4 & 8.5 & 12 & 25.5 & 23 & 48.9 & 8 & 17.1 & 47 & 100 \\
\hline \multicolumn{11}{|l|}{ Working Period } \\
\hline$<20$ Years & 4 & 16.7 & 10 & 41.6 & 6 & 25 & 4 & 16.7 & 24 & 100 \\
\hline$\geq 20$ Years & 0 & 0 & 2 & 8.7 & 17 & 73.9 & 4 & 17.4 & 23 & 100 \\
\hline Total & 4 & 8.5 & 12 & 25.5 & 23 & 48.9 & 8 & 17.1 & 47 & 100 \\
\hline \multicolumn{11}{|l|}{ Physical Fitness } \\
\hline Less & 2 & 4.6 & 11 & 25.6 & 22 & 51.2 & 8 & 18.6 & 43 & 100 \\
\hline Moderate & 2 & 50 & 1 & 25 & 1 & 25 & 0 & 0 & 4 & 100 \\
\hline Total & 4 & 8.5 & 12 & 25.5 & 23 & 48.9 & 8 & 17.1 & 47 & 100 \\
\hline \multicolumn{11}{|c|}{ Body Mass Index } \\
\hline Underweight & 0 & 0 & 1 & 100 & 0 & 0 & 0 & 0 & 1 & 100 \\
\hline Normal & 1 & 5.3 & 7 & 36.8 & 6 & 31.6 & 5 & 26.3 & 19 & 100 \\
\hline Overweight & 3 & 11.1 & 4 & 14.8 & 17 & 63 & 3 & 11.1 & 27 & 100 \\
\hline Total & 4 & 8.5 & 12 & 25.5 & 23 & 48.9 & 8 & 17.1 & 47 & 100 \\
\hline
\end{tabular}


(41.7\%) suffered from MSD with moderate severity level, and the other 3 respondents (12.5\%) suffered MSDs with severe severity level. Meanwhile, all respondents in the $\geq 44$ years old group suffered from MSDs, specifically 5 respondents $(21.7 \%)$ with mild severity level, 13 respondents $(56.5 \%)$ with moderate severity level, and 5 respondents $(21.7 \%)$ with severe severity level. Based on the correlation test result, the correlation coefficient score was 0.277 . It showed a weak correlation between age and MSDs.

\section{The Sex Based Cross Tabulation of Workers with MSDs in Circulator Loom Unit of PT. Kerta Rajasa Raya}

Based on the results of the cross tabulation in Table 9, it showed that the male respondents were more likely to suffer from MSDs with low intensity, as many as 5 people $(62.5 \%)$. Where as, the female respondents were more likely to suffer from MSDs with moderate severity level, as many as 21 people $(53.85 \%)$. According to the results of the chi square test, the score of the contingency coefficient was 0.365 . It indicated that there was a weak relationship between sex and MSDs.

\section{The Working Period Based Cross Tabulation of Workers with MSDs in Circulator Loom Unit of PT. Kerta Rajasa Raya}

Based on the results of the cross tabulation in Table 9, it can be concluded that out of 24 respondents who had a working period of $<20$ years, 4 of them (16.7\%) did not suffer from MSDs. Most of them were likely to suffer from mild severity level MSDs as many as 10 people (41.6\%). Furthermore, all of the respondents who had a working period of $\geq 20$ years suffered from MSDs. Most of them were likely to suffer from moderate severity level MSDs as many as 17 people (73.9\%). According to the results of the correlation test, the correlation coefficient was obtained at 0.402 . This indicated that there was a moderate correlation between working period with MSDs.

\section{The Body-Mass-Index Based Cross Tabulation of Workers with MSDs in Circulator Loom Unit of PT. Kerta Rajasa Raya}

Based on the results of the cross tabulation shown in Table 9, it can be concluded that the respondents who had Underweight Body Mass Index, as many as $100 \%$ of them suffered from
MSDs with mild severity level. The respondents who had normal Body Mass Index, as many as 7 people $(36.8 \%)$, suffered from MSDs with mild severity level. From 27 people respondents who had Overweight Body Mass Index, as many as 3 people (11.1\%) did not suffer from MSDs. Most of the respondents were likely to suffer from moderate severity MSDs as many as 17 people $(63 \%)$.

Based on the results of the correlation test, a correlation coefficient score of 0.046 was obtained. This indicated that there was a very weak correlation between Body Mass Index and the severity of MSDs.

\section{DISCUSSION}

The results of the Nordic Body Map questionnaire indicate that the employees of the Circulator Loom Unit in PT. Kerta Rajasa Raya commonly have moderate severity level MSDs, which is $53.5 \%$. One of the causes of the severity level of MSDs is the characteristics of the job that involve body muscles.

Based on the results of research, it was found that body parts that are likely to suffer from MSDs include neck, shoulders, back, waist, upper arm, wrist, knee, and leg. The complaint occurs because their works mostly require muscles of the body part. The workers who work as the machine operators do their jobs in standing position. This causes pain on the legs. The machine operators are also in charge of replacing thread rolls. This job is done by involving the upper extremity muscles.

The workers in the courier department are in charge of delivering a roll of yarn from the previous unit to the circulator loom unit. This requires the workers to walk around carrying heavy loads. Some work activities carried out by workers in the circulator loom unit. It has the potential to cause MSDs, because the characteristics of the job involve large repetitive movements and energy. This is in line with Health and Safety Executive (2017) statement that the causes of MSDs are multifactorial. The causes can come from jobs that require repetitive movements, force concentrated, and also the posture while working. In addition the conditions that may create MSDs to occur are psychosocial factors such as organisational culture, the health and safety climate and human factors. MSDs are caused by the combination and interaction of these factors.

Risk factors of the working posture in this study were measured by the REBA method. In this 
method, unnatural working posture can be seen from the final calculation of the results. Most of the workers have a moderate risk from their working posture, and the rest of them have low and high risks from their working postures. The results showed that the workers with moderate and high risk working postures suffer from MSDs complaints. As for the workers with the risk of a moderate and high working posture, they have a tendency to experience moderate and severe severity level of MSDs. The respondents with low risk working posture who suffer from MSDs with mild severity level have the same case as well. Some of the respondents do not experience MSDs.

MSDs complaints can be worse and its risk is higher when the position of the body is away from its natural position, and when body position is away from the center of gravity in humans during the works. This condition commonly happens due to task requirements, working equipment, and unsuitable workstations for workers (Tarwaka, 2013).

Working postures that are out of neutral position, joints problems and pains, aching muscles, and soreness increase fatigue and injury risk. Previous studies show body posture is a significant factor that causing MSDs (Claggett, 2002).

Another study by Santosa and Ariska (2018) has shown that working posture take an important part in causing MSDs. The result gives a positive relationship between working position and many MSDs complaints. Risky working positions will increase the number of MSDs complaints to workers.

In addition, the result shows respondents by age of $\geq 44$ years old tend to experience MSDs in moderate severity level compared to respondents who are $<44$ years old that mostly experience MSDs complaints in high severity level. This condition signifies that the more people get older, the more serious MSDs complaints they will get. Therefore, age factor may have a role in MSDs cases.

Along with increasing age, various changes will occur in the human body. Various physiological functions have started to seem to decrease after age 30 years, so that someone who's been at elder age will experience changes and a decrease in all the functions of the organs of the body that cannot be avoided, without exception on the system Musculoskeletal. Changes in the form of reduced bone tissue and bone size, this caused stiffness and loss of strength and that would have lead on the occurrence of osteoporosis, the onset of pain, deformities, and fractures (Timiras and Navazio, 2008).

According to Tarwaka (2013), there are several studies about age and MSDs complaints relationship. The first study is conducted by Batti'e et al. (1898) which shows maximal muscle power happens at age 20-29 years old, henceforth it will weaker in line with the increasing age. When human reaches the age of 60 years old, his muscle power declines to $20 \%$ on average. The risk of msucle complaints more increase when muscle power decreases.

The next study is conducted by Pratama (2017) about the high number of MSDs cases in elderly workers. It shows 9 workers $(47.4 \%)$ experience MSDs in moderate risk, and 5 workers $(26.3 \%)$ experience higher risk of 19 workers in total, who are more than 41 years old.

According the result, 39 female respondents in total, around 35 people experience MSDs complaints and 4 of them do not. Meanwhile, male respondents in total experience MSDs complaints. In this study, male respondents who suffer MSDs are caused by their heavier work activities and musle works. Based on the calculation using REBA method, this condition includes in high risk working postures category.

Moreover, male respondents mostly suffer MSDs in lower level in contrast to female respondents who experience MSDs in moderate level. This condition shows the sex factor can cause MSDs.

Tarwaka (2013) explain muscle power in females is two-thirds of muscle power in males. As the result, muscle endurance in males is higher than in females. The result from Betti'e et al. (1989) shows female muscle is around $60 \%$ male muscle power in average (Tarwaka, 2013).

Another research done by Santosa and Ariska (2018) shows gender takes part in causing MSDs. It proves female workers more experience MSDs complaints compared to male workers.

In the result, there are 4 respondents with $<20$ years of working period do not experience MSDs. Most of those workers experience MSDs in mild severity level. On the other hand, workers with $\geq 20$ years of working period mostly experience MSDs in moderate severity level. This condition signifies the longer the working period of workers have, the more they will experience MSDs in more serious level of severity. Therefore, the length of working period can be a factor in causing MSDs in workers. 
Working period is a factor related to the workers Length of service in a company. The longer of the exposure will increase the risk of MSDs, because MSDs takes a long time to develop and manifest to be a clinical disease. In other words, the longer years of working period of an employer, the more he will experience MSDs complaint. The result of the study shows the increase of sick leave duration of new workers during second years. This condition may get worse due to the increase of exposure time (Häkkänen, Viikari-Juntura and Martikainen, 2001).

The result of the study shows that respondents with less of physical fitness tend to experience more serious MSDs severity level compared to respondents with moderate physical fitness, and the majority of respondents with less of physical fitness experience MSDs in moderate level. Based on the previous result, physical fitness can be an influence factor of MSDs in workers.

Physical fitness is one of the important factors related to MSDs because it consists of cardiorespiratory endurance components, muscle endurance, muscle power, body composition, and flexibility (Caspersen, Powell and Christenson, 1985). The cardiorespiratory system efficiency is an essential component in physical fitness. Muscles are not able to do contraction without oxygen, and cardiorespiratory system supplies oxygen to cells.

Researches have shown that workers with higher Body Mass Index tend to experience MSDs. Overweight category may lead to be a factor in the increase of physiological burden and mechanical tissue (Sethi, Sandhu and Imbanathan, 2011). The heavier body mass will encumber the spinal column and lower extremities which cause structural degeneration and pain (Das and Mukhopadhyay, 2016).

The result of the study shows most of respondents with a Overweight Body Mass Index experience MSDs in moderate severity level, meanwhile, respondents with a Underweight and normal Body Mass Index experience MSDs in lower severity level. Based on the result, the Overweight Body Mass Index respondents will more experience MSDs in serious way. The previous condition signifies the number of Body Mass Index become factor that influence MSDs. However, based on the correlation analysis, the result shows correlation coefficient around 0.046. It means the correlation between Body Mass Index and MSDs is weak. On the other hand, there are still respondents with normal Body Mass Index experience MSDs in moderate to higher severity level. This condition is caused by Body Mass Index, which may becomes the lower risk factor of MSDs. Furthermore, body mass does not calculate a person's body composition that creates different effects in pain incident. Das and Mukhopadhyay (2016) consider one of MSDs prevalence is due to the increase of Body Mass Index. However, below normal standards of body composition such as fat mass, lean mass, fat $\%$, and Waist-Hip Ratio (WHR) are related to MSDs complaint.

\section{CONCLUSION}

Working postures factors have an important role in causing MSD. Based on the correlation test result, it showed strong correlation. Another factor that cause MSDs is the working period, based on the correlation test result, it showed moderate correlation. Other factors that have a minor role in causing MSDs are age, sex, which has low relationship, Body Mass Index, and physical fitness that has the lowest relationship.

\section{ACKNOWLEDGEMENT}

The author express their sincere gratitude to $\mathrm{Mr}$. Nanda, Mr. Ilham, and all those PT. Kerta Rajasa Raya workers who rendered immense co-operation during the completion of this research. The author would also like to thank Mr. Sho'im Hidayat, dr., M.S., the research supervisors, for his patient guidance, enthusiastic encouragement and useful critiques of this research.

\section{REFERENCES}

Batti'e, M. et al. (1898) 'Isometric Lifting Strength As a Predictor of Industrial Back Pain Reports', Spine, 14(8), pp. 851-856.

Bureau of Labor Statistic (2017) 2016 Survey of Occupational Injuries \& Illnesses Charts Package. Washington DC: United States Department of Labor.

Caspersen, C. J., Powell, K. E. and Christenson, G. M. (1985) 'Physical Activity, Exercise, and Physical Fitness : Definitions and Distinctions for Health-Related Research', Publich Health Report, 100(2), pp. 126-131.

Claggett, C. L. (2002) An Analysis of the Prevalence of Musculoskeletal Disorders in Heavy, Civil 
Construction Operation and the Impact of Job, Age, and Experience. Research Paper. Memomonie: Masters of Science Degree, University of Wisconsin-Stout.

Das, S. K. and Mukhopadhyay, S. (2016) 'Effect of Altered Body Composition on Musculoskeletal Disorders in Medical Practitioners', International Journal of Research in Engineering and Technology, 5(16), pp. 1-6.

Ghosh, T. (2015) 'Assessment of Postural Effect on Work Related Musculoskeletal Disorders and Back Muscle Fatigue among the Goldsmiths of India', International Journal of Occupational Safety and Health, 5(2), pp. 16-22.

Häkkänen, M., Viikari-Juntura, E. and Martikainen, R. (2001) 'Job experience, Work Load, and Risk of Musculoskeletal Disorders', Occupational and Environmental Medicine, 58(2), pp. 129-135

Health and Safety Executive (2017) 'Work-related Musculoskeletal Disorders (WRMSDs) Statistics in Great Britain 2017'. Liverpool: Health and Safety Executive.

International Labour Organization (2013) 'Occupational Safety and Health: Means for Productivity'. Geneva: International Labour Organization.

Khudhir, K. et al. (2017) 'Association Between WorkRelate Musculoskeletal Disorder and Ergonomic Risk Factors Among Nursing Professionals in Ranya and Qaladiza Districts', Kurdistan Journal of Applied Research, 2(2), pp. 1-6.
Pratama, D. N. (2017) 'Identifikasi Risiko Musculoskeletal Disorders (MSDs) Pada Pekerja Pandai Besi', The Indonesian Journal of Occupational Safety and Health, 6(1), pp. 78-87.

Randang, M. J., Kawatu, P. A. T. and Sumampouw, O. J. (2017) 'Hubungan antara Umur, Masa Kerja dan Lama Kerja dengan Keluhan Musculoskeletal pada Nelayan di Desa Talikuran Kecamatan Remboken Kabupaten Minahasa', Media Kesehatan, 9(3), pp. 1-8.

Santosa, A. and Ariska, D. K. (2018) 'Faktorfaktor yang Berhubungan dengan Kejadian Musculoskeletal Disorders pada Pekerja Batik di Kecamatan Sokaraja Banyumas', MEDISAINS: Jurnal Ilmiah Ilmu-ilmu Kesehatan, 16(1), pp. 42-46.

Sethi, J., Sandhu, J. S. and Imbanathan, V. (2011) 'Effect of Body Mass Index on Work Related Musculoskeletal Discomfort and Occupational Stress of Computer Workers in a Developed Ergonomic Setup', Sports Medicine, Arthroscopy, Rehabilitation, Therapy \& Technology, 3(22), pp. 1-7.

Tarwaka (2013) Ergonomi Industri: Dasar-Dasar Pengetahuan Ergonomi dan Aplikasi di Tempat Kerja. Solo: Harapan Press.

Timiras, P. S. and Navazio, F. M. (2008) 'The Skeleton, Joints, and Skeletal and Cardiac Muscles', in Physiological Basis of Aging and Geriatrics. 4th edn. Florida: CRC Press. 